\title{
TANULÁSBAN AKADÁLYOZOTT FIATALOK JÖVŐKÉPÉNEK VIZSGÁLATA
}

\section{Szerzők:}

\author{
Molnár Alexandra \\ Nyíregyházi Bárczi Gusztáv Általános Iskola, \\ Készségfejlesztő Iskola, Kollégium és EGYMI \\ (Magyarország) \\ Mező Katalin (PhD.) \\ Debreceni Egyetem (Magyarország) \\ Levelező szerző e-mail címe: \\ kata.mezo1@gmail.com
}

\section{Lektorok:}

Kelemen Lajos (PhD.)

Poliforma Kft.

Mező Ferenc (PhD.)

Eszterházy Károly Katolikus Egyetem

( Magyarország)

Molnár Alexandra, Mező Katalin (2021). Tanulásban akadályozott fiatalok jövőképének vizsgálata. Különleges Bánásmód, 7. (3). 57-67. DOI 10.18458/KB.2021.3.57

\begin{abstract}
Absztrakt
Hattér és célkitüzések: a tanulásban akadályozott fiatalok jövőképének vizsgálata ritkán kerül a kutatások fókuszába (Mártonfi, 2011; Móré és Mező, 2016), holott a sikeres, boldog élet alapja, hogy mindenki a saját céljainak megfelelően tudja megvalósítani önmagát. Jelen tanulmány a tanulásban akadályozott fiatalok jövőképével foglalkozik, célunk, annak megismerése, hogy a tanulásban akadályozott fiataloknak milyen életcéljaik illetve kilátásaik vannak az életre vonatkozóan. Módszer: vizsgálatunkban szakiskolába járó tanulásban akadályozott fiatalok $(\mathrm{N}=46)$, valamint az őket oktató szakiskolában tanító pedagógusok (N=76) kérdőíves megkérdezésére került sor, a válaszokat SPSS program használatával értékeltük, leíró statisztika, valamint Spearman's-féle rangkorreláció alkalmazásával. Eredmények: A szakiskolába járó tanulásban akadályozott fiatalok életcéljai között a boldog élet $\left(r_{s}=0,43\right)$, a siker $\left(r_{s}=0,45\right)$, és a munka $\left(r_{s}\right.$ $=0,45)$ szerepel, a családalapítás ebben az életkorban háttérbe szorul. A fiatalok életcéljai és a továbbtanulás között nincs szoros összefüggés. A szakiskolába járó tanulásban akadályozott fiatalokat oktató pedagógusok véleménye alapján a szakma elsajátításának sikeressége és a munkaerő-piacon való helytállás között nincs szignifikáns kapcsolat. Életkilátásként viszont a pedagógusok egy része elképzelhetőnek tartja a családalapítást a tanulásban akadályozott fiatalok esetében is.
\end{abstract}

Kulcsszavak: tanulásban akadályozottság, életcél, jövőkép, munkaerôpiac, család

Diszciplina: gyógypedagógia 


\begin{abstract}
THE EXAMINATION OF YOUNG PEOPLE WITH LEARNING DIS ABILITIES ABOUT THEIR VISION OF FUTURE

Background and Objectives: the examination of the vision of the future of young people with learning disabilities it rarely comes into the focus of research (Mártonfi, 2011; Móré and Mezó, 2016), though the foundation of a successful, happy life is that everyone can realize themselves according to their own goals. The present study deals with the vision of the future of young people with learning disabilities. Our aim is to find out what have life goals and prospects of young people with learning disabilities. Methods: the participants were youngsters with learning disability attending vocational school $(N=46)$ and their teachers $(N=76)$, and the answers we were evaluated using SPSS, descriptive statistics, and Spearman's rank correlation. Results: The life goals of young people with learning disabilities in vocational schools have a bappy life (rs $=0.43$ ), success (rs $=0.45)$, and work ( $r s=0.45)$, and starting a family is pushed into the background at this age. There is no strong correlation between young people's life goals and further education. According to the opinion of teachers, there is no significant relationship between the success of acquiring a profession and their standing in the labor market. From a life perspective, some educators consider starting a family conceivable for young people with learning disabilities.
\end{abstract}

Keywords: learning disabilities, life goal, future, labor market, family

Disciplines: special education

Napjainkban a szakképzés nagy átalakulását, reformját éljük. A Kormány 2019-ben elfogadta, majd 2020-tól megvalósításra bocsátotta a Szakképzés 4.0 Stratégiai Programot, mely egy új szemléletmódú, a szakmai- és felnőttképzés rendszerszintú megújitását, továbbfejlesztését célzó változtatást célzott meg.

A szakképzés, a felsőfokú szakképzettséget nem igénylő munkakör betöltéséhez, vagy tevékenység végzéséhez szükséges szakmára felkészítő szakmai oktatásra és szakképesítésre felkészítő szakmai képzésre irányul. Ebben a képzési keretben jelennek meg a szakiskolák, melyek elsődlegesen „a többi tanulóval, a fogyatékossága miatt együtt haladásra képteleneket készíti fel szakmai vizsgára, vagy nyújt részükre munkába álláshoz és életkezdéshez szükséges ismereteket" (2011 évi tv. a köznevelésről, 2019. évi LXXX tv. a szakképzésről). Az integráltan vagy szegregáltan nevelt tanulásban akadályozott, sajátos nevelési igényú fiatalok, abban az esetben, ha a nyolc általános elvégzése után tovább tanulnak, akkor jelentős többségben ezekben a szakiskolai intézményekben keresnek lehetőségeket (bővebben Mező K., 2021). Jelen tanulmányban a szakiskolába járó tanulásban akadályozott fiatalok életcéljaira és életkilátásaira fókuszálunk. Tesszük ezt egyrészt azért, mert csekély számú kutatás létezik a témára vonatkozóan (Mártonfi, 2011; Szekeres, 2014; Móré és Mező K., 2016; Müller, 2017; Török, 2017, Mező K. 2021); másrészt abból a kíváncsiságból fakadóan, hogy megismerjük és összevessük a tanulásban akadályozott fiatalok jövőelképzeléseit a velük foglalkozó pedagógusok realitáson nyugvó gondolataival.

\section{Életcélok és életkilátások}

Az életcélok az emberek által legfontosabbnak tartott állapotok, tárgyak, eszmények. Többnyire a társas kapcsolatok, a jómód, a munka és a teljesítmény azok a legfőbb jellemzők, amelyek az életcélok körébe tartoznak (Emmons 1999, Ryan, Sheldon, Kasser és Deci, 1996). 
Megkülönböztetünk extrinzik és intrinzik életcélokat. Az extrinzik célok közé tartozik például a külső megjelenés, az anyagiak, míg az intrinzik törekvésekhez a fejlődés és a kapcsolatok fontossága sorolható. Az emberek különbözőségét, többek között az adja, hogy más-más életcéljuk, elképzeléseik, kilátásaik vannak az életre vonatkozóan, másképpen értelmeznek bizonyos helyzeteket, más a szociális hátterük, más neveltetésben részesülnek, más a személyiségük is (Molnár, 2020). Emmons (1996) azt állítja, hogy boldogabbak azok az emberek, akiknek vannak céljaik az életben, mint, azok, akik-nek nincsenek.

Az életkilátást többnyire orvosi, egészségügyi értelemben használják az élettartam és a halandóság összefüggésében. Jelen tanulmányunkban azonban az életkilátás értelmezési kereteinek kiszélesítésére törekszünk, egyetértve Hablicsek és Kovács (2007) azon kutatásaival, melyben rámutatnak arra, hogy ,vitathatalan, hogy az iskolai végzettség a társadalomban elfoglalt pozíció egyik leglényegesebb indikátora, és az sem megkérdőjelezhető, hogy a tudás azon különbségeinek, amelyek különféle iskolai végzettségi szintekhez kapcsolódnak, jelentős szerepük van az emberek egészségi állapotának, halandósági esélyeinek alakulásában. Az iskolai végzettség a társadalmi pozíció szempontjából ennél jóval többet jelent: nagymértékben befolyásolja a munkához jutás esélyeit, a végzett munka minőségét, díjazását és sok más, a halandóság szempontjából fontos körülményt” (Hablicsek és Kovács, 2007, 7.).

Mindent összevetve, az életkilátást, mintegy a személy számára egy életút távlatában várhatóan bekövetkező események összességét értelmezzük, amelyek befolyásolják az egyén egészségügyi, társadalmi-szociális és legfőképpen munkaerőpiaci elhelyezkedési esélyeit (Mező és Mező, 2020). Az emberek életkilátásait több tényező befolyásolhatja például: 1) egészségi állapot, 2) az iskolázottság, 3) a munka/jövedelmi helyzet, 4) az életkörülmény, 5) az életmód és 6) a szociális-egészségügyi ellátórendszer felkészültsége.

$\mathrm{Az}$ életcélok és az életkilátások azonban nem minden esetben egyeznek.

\section{A tanulásban akadályozott fiatalok jövőképe}

A jövőkép, az egyén által kitűzött azon célok összessége, melyeket meghatározott időintervallumban próbál meg elérni. Magában foglalja az egyén életcéljait és életkilátásait egyaránt (Mező és Mező, 2020). A jövőkép az adott személy jövőjéről alkotott saját véleményét, elgondolását, terveit jelenti, amelyért tenni fog, hogy elérje a kitűzött célt (Molnár, 2020). Minél idősebb egy ember, annál konkrétabbá és reálisabbá válik a jövőről alkotott képe. A tanulásban akadályozott fiatalok jövőképét több tényező is befolyásolhatja:

- az akadályozottság mértéke: A központi idegrendszer sérülésének mértéke, valamint a szociális környezet hatása befolyásolhatja az akadályozottság súlyosságát. Amennyiben a tanulásban akadályozott fiatal önálló életvezetésre képes, úgy a jövőképe pozitívan alakulhat. Más esetben - az önállóság vagy szülői támogatás, segítség hiányában - a jövőkép is negatív irányba terelődhet, a fiatal és ezzel együtt a szülők számára.

- az intelligenciaszint: a betegségek nemzetközi osztályozására (BNO) szolgáló kódrendszer alapján az enyhe értelmi fogyatékos személyek intelligenciaszintje 69 és 50 között van. Az alacsony intelligenciaszint hatással lehet a fiatal képességfejlődésére, mely meghatározza a továbbtanulási, majd a munkaerőpiaci elhelyezkedési, családalapítási esélyeit is.

- a családi/szociális háttér: A család pénzügyi helyzete, szakképzettsége, értékrendszere, valamint a családtagok által közvetített minták befolyásolják a tanulásban akadályozott fiatal jövőképét. A családnak, mint az elsődleges szocializációs színtérnek nagy jelentősége van 
abban, hogy a gyermeknek milyen céljai lesznek az életben, szeretne-e majd tanulni, dolgozni, családot alapítani. Amennyiben a szülő ellenségesen viszonyul az iskolához, oktatáshoz, úgy a gyerek tanulási motivációja, érdeklődése is csökken és a fiatal tanulmányaira negatívan hat (Lányiné, 2017).

A családi háttér a nyelvi fejlődésre is hatással van, Bernstein (1975) például az úgynevezett „korlátozott nyelvi kód” kifejezést használta, abban az esetben, ha a család kevesebb szókinccsel kommunikál és nem teljes mondatba foglalt közléseket határoz meg. Ez is negatívan befolyásolhatja a tanulásban akadályozott fiatal jövőképét, hiszen hátrányban lesz társaihoz képest a kommunikációban, a beszéd megértésében.

- a tanulmányok elérhetôsége: a tanulásban akadályozott fiatalok továbbtanulási lehetősége a szakiskolára korlátozódik. Ez magyarázható a gyengébb értelmi képességekkel, valamint az általános iskolában elsajátított csökkentett és specializált tudástartalmak miatti különbséggel. A szakiskolákban a tanulásban akadályozott fiatalok számára felkínált és választható szakmák, vagy résszakképesítések változatossága meg sem közelíti az átlagos képességekkel rendelkező tanulók számára ajánlott szakmák mennyiségét. Mindez a későbbiekben a munkaerôpiaci elhelyezkedést is beszúkíti (Mező K., 2021), s emellett az is gondot jelent, hogy a felnőttképzésbe való bekapcsolódásra is csak ritkán nyílik alkalom ezen fiatalok számára.

- munkaerőpiacon való elhelyezkedésének lehetősége: a tanulásban akadályozott fiatal számára is a munkavállalás teremti meg az anyagilag függetlenné válás biztonságát. Ehhez nélkülözhetetlen egy jól felépített rendszer. Szükség van egy jó oktatási rendszerre, ahol a fiatalok megkapják a megfelelő ismeretet az adott szakmáról. Fontos, hogy legyen le- hetőség gyakorlatra, ahol alkalmazni tudják a megszerzett ismereteket. Végül talán a legfontosabb a társadalmi elfogadás, befogadás, megértés, az esélyegyenlőség, az, hogy a munkáltatók bizalmat és munkát adjanak a tanúlásban akadályozott emberek számára is. A munkaerőpiacon való elhelyezkedés leginkább hátráltató tényezői a társadalmi meg nem értettség, az elutasítás olykor a kirekesztés problémája, illetve a munkaerôpiaci foglalkoztatási lehetőségek hiánya (Mártonfi, 2011; Lányiné 2017).

- az adott társadalom befogadása/elfogadása: tanulásban akadályozott személy esetén a képesség sérülése és a személy eltérő fejlődése mellett a szocializációs folyamat zavarával is számolni kell (Goslin, 1969). A megfelelő jövőkép kialakulásához segíteni kell a fogyatékossággal élő személyek társadalmi integrációját és a befogadó attitűdök kialakulását.

- önelfogadás: az akadályozott személy nehezebben tudja kialakítani reális énképét, ebben a környezetnek jelentős szerepe van a visszajelzések, viszonyulások által. Az akadályozott személy esetében a reálisénkép kialakítása után - amennyiben ez sikeres - el kell fogadnia önmagát olyannak, amilyen és ez egy újabb lépcsőfok a teljes önelfogadáshoz. Az önelfogadás és a pozitív énkép sokat segíthet a reális jövőkép kialakításában.

A tanulásban akadályozott fiatalok jövőképének megismerésére irányuló vizsgálat tapasztalatai

A tanulmányban megjelenő vizsgálatban a szakiskolába járó tanulásban akadályozott fiatalok életcéljainak a megismerésére törekedünk, melyet összevetettük az őket tanító, szakiskolában dolgozó pedagógusoknak, a tanulók életkilátásaira vonatkozó véleményével. Az életcélok tekintetében arra 
kerestük a választ, hogy a szakiskolába járó tanulásban akadályozott fiatalok mit gondolnak saját életükről, jövőképükről, az életcélok között milyen preferenciákkal találkozunk pl. a továbbtanulás, a szakma elsajátítás, a munkaerőpiaci elhelyezkedés, a családalapítás tekintetében. A tanulásban akadályozott fiatalok életkilátásaira vonatkozó tapasztalatokat a pedagógusok válaszadásaiból ismerhetünk meg.

Előfeltevéseink a következők voltak: 1) Feltételeztük, hogy a szakiskolába járó tanulásban akadályozott fiatalok céljai között elsődleges helyen szerepel a családalapítás, így a tanulásban akadályozott fiatalok életcéljaira és a családalapításra vonatkozó adatok között szoros korreláció jelenik meg. 2) Úgy véltük, hogy a szakiskolába járó fiatalok életcéljai között nem szerepel a továbbtanulás. 3) Feltételeztük, hogy a szakiskolába tanító pedagógusok úgy vélik, hogy a szakiskolába járó tanulásban akadályozott fiatalok esetében a tanult szakma elsajátításának sikeressége összefüggésben van azzal, hogy képesek lesznek-e a későbbiekben megállni a helyüket a tanult szakmájukban. 4) Feltételeztük, hogy a szakiskolába tanító pedagógusok úgy vélik, hogy a szakiskolába járó tanulásban akadályozott fiatalok alkalmasak a családalapításra, valamint, hogy el fogják tudni tartani családjukat és meg fognak tudni adni számukra mindent, amire szükségük lehet az életük során.

\section{1. ábra. Nemi eloszlás - fiatalok/fö. (Forrás: Sžrzö́k).}

Nemi eloszlás - fiatalok

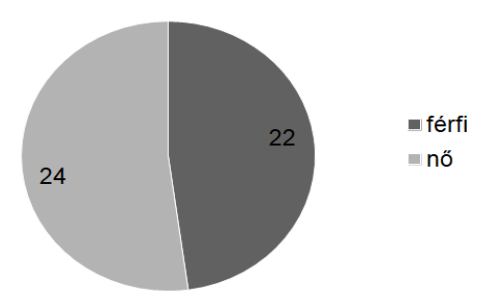

\section{Módszer}

A vizsgálat során két különböző kérdőív felvételére került sor, melyből az egyiket a szakiskolába járó tanulásban akadályozott fiatalok töltötték ki, a másikban pedig a fiatalokat oktató pedagógusok fogalmazhatták meg véleményeiket. A fiataloknak készített kérdőívben össze-sen 14 kérdés található. 3 feleletválasztós, 6 nyitott kérdés, 3 skála - ebből 2 darab 5 fokozatú és 1 darab 3 fokozatú skála - és 2 rövid válaszos kérdés. A fiatalokat tanító pedagógusoknak készített kérdőívben 9 kérdés található, amiből 1 nyitott kérdés, 1 feleletválasztós, 3 rövid válaszos valamint 4 skála jelenik meg. A válaszok elemzését SPSS program segítségével, leíró statisztika valamint Spearman's féle rangkorreláció alkalmazásával végeztük el.

\section{Minta}

A kutatásban szakiskolába járó tanulásban akadályozott fiatalok ( $\mathrm{n}=46$ ) és őket oktató pedagógusok $(n=76)$ vettek részt. A fiatalok esetében 24 nő és 22 férfi adott választ (1. ábra), a pedagógusoknál pedig 63 nő és 11 férfi válaszolt ( 2. ábra) a kérdőívben szereplő kérdésekre.

A pedagógusok nemi aránya megfelel a közoktatás indikátorrendszere 2019-ben bemutatásra került adatokhoz, mely szerint az összes fóállású (teljes munkaidôs) pedagógus több mint 80 százaléka nő (KRTK KTI, 2019).

\section{2. ábra. Nemi eloszlás-pedagógusok/föo.(Forrás:Szerzöke).}

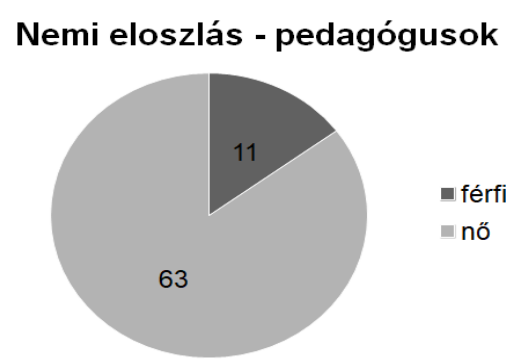


A vizsgálatra 2020-ban került sor, a vizsgálat elvégzését nehezítették a Covid-19 vírus miatt kialakult járványügyi intézkedések, melynek következtében a kérdőívek kitöltésének száma is korlátozott volt. A későbbiekben célunk a mintát bővíteni, annak érdekében, hogy egy komplex és reprezentatívabb képet kapjunk az adott témáról.

\section{Eredmények}

A vizsgálatunk első egysége annak megismerésére irányult, hogy a tanulásban akadályozott szakiskolába járó fiatalok milyen életcélokkal rendelkeznek. Feltételeztük, hogy a szakiskolába járó tanulásban akadályozott fiatalok céljai között elsődleges helyen szerepel a családalapítás, így a tanulásban akadályozott fiatalok és a családalapításra vonatkozó adatok között szoros korreláció jelenik meg.

A vizsgálati eredmények arra engednek következtetni, hogy a szakiskolába járó tanulásban akadályozott fiatalok életcéljai és a családalapítás között nincs együttjárás $\left(r_{s}=0,15 ; p \leq 0,33-1\right.$. táblázat). A szakiskolába járó fiatalok céljai között nem a családalapítás dominál, sokkal fontosabb hogy tudjanak spórolni $\left(r_{s}=0,53\right)$, a boldog élet $\left(r_{s}=0,43\right)$, a siker $\left(r_{s}=0,45\right)$, és a munka $\left(r_{s}=0,45\right)$, s a családalapítás fontossága ezekhez képest háttérbe szorult $\left(r_{s}=0,15\right)$. Emellett fontosnak tartják, hogy anyagi biztonságban legyenek, hogy eltudják tartani önmagukat és családjukat $\left(r_{s}=0,33\right)$, és, hogy mindent megtudjanak adni a gyermekeiknek $\left(r_{s}=0,43\right)$.

Az életcélokra vonatkozó második hipotézisünk az volt, hogy a tanulásban akadályozott fiatalok céljai között nem fog megjelenni a továbbtanulás (esetükben más szakma tanulása), és azt gondoltuk, hogy nincs összefüggés a két tényező között. A hipotézist igazoltuk (2. táblázat), a tanulásban akadályozott fiatalok életcéljai között nem szerepel a továbbtanulás elsődleges helyen $\left(r_{s}=0,24\right)$. Azonban fontos azt kiemelni, hogy az önálló vélemények megfogalmazására alkalmas kérdéseknél, néhány tanuló (2 fö) arról számolt be, hogy nyitottak lennének a más szakma elsajátítása irányába, és gondolkoznak más szakma elsajátításában is, ugyanakkor a fiatalok többsége arról számolt be, hogy szereti azt a szakmát, amit éppen tanul.

Vizsgálatunk második egységében a pedagógusokat kérdeztük a tanulásban akadályozott szakiskolába járó fiatalok életkilátásaira vonatkozóan. Célunk annak megismerése, hogy a pedagógusok milyen véleménnyel vannak a fiatalok jövőképével kapcsolatban (3. táblázat). Elsősorban a tanulmányoktól a munka világába történő átmenetre, a pénzgazdálkodásra és a családalapításra összpontosítottunk.

1. táblázat. A tanulásban akadályozott fiatalok életcéjjai - családalapitás. (Forrás: Szerzöke).

\begin{tabular}{|l|l|l|r|}
\hline \multicolumn{2}{|c|}{ Változók } & \multicolumn{2}{c|}{ Családalapítás } \\
\hline $\begin{array}{l}\text { Spearman-féle } \\
\text { rangkorreláció }\end{array}$ & Vannak céljai az életben. & $\mathrm{r}_{\mathrm{s}}$ & 0,15 \\
\cline { 3 - 4 } & & $\mathrm{p}$ & 0,33 \\
\cline { 3 - 4 } & $\mathrm{n}$ & 46 \\
\hline
\end{tabular}


2. táblázat. A tanulásban akadályozott fiatalok életcéljai-más szakma tanulása. Forrás: Szerzọo.k.

\begin{tabular}{|l|l|l|r|}
\hline \multicolumn{2}{|c|}{ Változók } & Más szakma tanulása. \\
\hline $\begin{array}{l}\text { Spearman-féle } \\
\text { rangkorreláció }\end{array}$ & Vannak céljai az életben. & $\mathrm{r}_{\mathrm{s}}$ & 0,24 \\
\cline { 3 - 4 } & $\mathrm{p}$ & $\mathrm{p}$ & 0,10 \\
\cline { 3 - 4 } & $\mathrm{n}$ & 46 \\
\hline
\end{tabular}

3. táblázat. A tanulásban akadályozott fiatalok életkilátásaira vonatkozó pedagógusi vélemények közötti együ̈tjárások. Forrás: Szerzọk.

\begin{tabular}{|c|c|c|c|c|c|c|c|}
\hline Vélemény & $\begin{array}{l}\text { Fiatalt } \\
\text { érdekli } \\
\text { a jövője }\end{array}$ & $\begin{array}{l}\text { A fiatal a } \\
\text { társadalom } \\
\text { aktív tagja }\end{array}$ & $\begin{array}{l}\text { Többsé- } \\
\text { güknek } \\
\text { lesz } \\
\text { munkája }\end{array}$ & $\begin{array}{c}\text { El tudják } \\
\text { önállóan } \\
\text { intézni } \\
\text { saját } \\
\text { ügyeit }\end{array}$ & $\begin{array}{l}\text { Mindig } \\
\text { szüksége } \\
\text { lesz } \\
\text { segítségre } \\
\text { az élete } \\
\text { során }\end{array}$ & $\begin{array}{l}\text { Jól fog } \\
\text { tudni } \\
\text { bánni a } \\
\text { pénzzel }\end{array}$ & $\begin{array}{c}\text { Munka- } \\
\text { erôpiacon } \\
\text { hátrányban } \\
\text { lesznek }\end{array}$ \\
\hline $\begin{array}{l}\text { A fiatal a társadalom } \\
\text { aktív tagja }\end{array}$ & $0,53^{* *}$ & & & & & & \\
\hline $\begin{array}{l}\text { Többségüknek lesz } \\
\text { munkája }\end{array}$ & $0,32^{* *}$ & $0,47^{\text {** }}$ & & & & & \\
\hline $\begin{array}{l}\text { El tudják önállóan } \\
\text { intézni saját ügyeit }\end{array}$ & 0,09 & $0,34^{* *}$ & $0,38^{* *}$ & & & & \\
\hline $\begin{array}{l}\text { Mindig szüksége lesz } \\
\text { segítségre az élete során }\end{array}$ & $-0,11$ & $-0,11$ & $-0,16$ & $-0,06$ & & & \\
\hline $\begin{array}{l}\text { Jól fog tudni bánni a } \\
\text { pénzzel }\end{array}$ & $-0,06$ & 0,05 & $0,31^{* *}$ & $0,46^{* *}$ & $-0,13$ & & \\
\hline $\begin{array}{l}\text { Munkaerôpiacon } \\
\text { hátrányban lesznek }\end{array}$ & $0,24^{*}$ & $-0,14$ &,$- 38^{* *}$ & $-0,17$ & $0,33^{* *}$ & $-0,53^{* *}$ & \\
\hline $\begin{array}{l}\text { Képes megállni a helyét } \\
\text { a szakmájában }\end{array}$ & $0,32^{* *}$ & $0,38^{* *}$ & $0,35^{* *}$ & $0,40^{* *}$ & $-0,11$ & 0,16 & 0,02 \\
\hline
\end{tabular}

* A cellákban lévő értékek $p \leq 0,05$ szinten szignifikáns Spearman-féle $\left(r_{s}\right)$ rangkorrelációk ** A cellákban lévő értékek $p \leq 0,01$ szinten szignifikáns Spearman-féle $\left(r_{s}\right)$ rangkorrelációk

A pedagógusok véleménye tekintetében több figyelemreméltó eredményre jutottunk (3.táblázat). A pedagógusok úgy vélik, hogy ha a tanulásban akadályozott fiatalt érdekeli a jövője, akkor a társadalom aktív tagjaivá fog válni $\left(\mathrm{r}_{\mathrm{s}}=0,52\right)$; valamint a jövő iránt érdeklődő fiatalok többsé- gének lesz munkája is $\left(r_{s}=0,32\right)$ és képesek lesznek megállni a helyüket a szakmájukban $\left(r_{s}=0,32\right)$. Ugyanakkor érdekes, hogy ennek ellenére a pedagógusok úgy vélik, hogy ezek a tanulásban akadályozott fiatalok is hátrányban lesznek a munkaerőpiacon $\left(\mathrm{r}_{\mathrm{s}}=0,24\right)$. Akinek munkája lesz, azoknak 
a pénzügyek tekintetében van esélye arra, hogy ügyeket tudjanak intézni $\left(r_{s}=0,38\right)$ és pénzzel tudjanak bánni $\left(\mathrm{r}_{\mathrm{s}}=0,31\right)$. Mérsékelt negatív irányú korreláció $\left(r_{s}=-0,53\right)$ a pénzzel való bánni tudás és a munkaerőpiaci hátrány között. A pedagógusok úgy vélik, hogy a munkaerőpiaci hátrány velejárója, hogy a fiatalok nem tudnak jól bánni a pénzzel.

Következő felvetésünkben abból indultunk ki, hogy a szakiskolában tanító pedagógusok úgy vélik, hogy a szakiskolába járó tanulásban akadályozott fiatalok esetében a tanult szakma elsajátításának sikeressége összefüggésben van azzal, hogy képesek lesznek-e a későbbiekben megállni a helyüket a munkaerőpiacon a tanult szakmájukban.

A pedagógusok válaszait értelmezve figyelemreméltó tapasztalathoz jutottunk: a pedagógusok véleménye szerint a fiatalok jól elsajátított szakmája és a munkaerôpiacon való helytállásuk nem mutat összefüggést (4. táblázat; 4. ábra). A pedagógus tehát úgy gondolják, hogy az általuk képzett tanulók nem biztos, hogy meg fogják állni a helyüket a munkaerőpiacon a szakmájukban. Ez a pedagógusi vélemény nem túl kedvező az életkilátások tekintetében a tanulásban akadályozott fiatalok számára.

4. táblázat. A tanulásban akadályozott fiatalok életkilátásaira vonatkozó pedagógusi vélemények közötti a szakma jó elsajátitása és a belytállás a szakmában együttjárás tekintetében. Forrás: Szerzọk.

\begin{tabular}{|l|l|l|r|}
\hline \multicolumn{2}{|c|}{ Változók } & $\begin{array}{c}\text { Képesek jól megállni } \\
\text { helyüket a } \\
\text { szakmájukban. }\end{array}$ \\
\hline $\begin{array}{l}\text { Spearman-féle } \\
\text { rangkorreláció }\end{array}$ & $\begin{array}{l}\text { Képesek jól elsajátítani a } \\
\text { szakmát. }\end{array}$ & $\mathrm{r}_{\mathrm{s}}$ & $-0,09$ \\
\cline { 3 - 4 } & $\mathrm{p}$ & $\mathrm{n}$ & 0,44 \\
\cline { 2 - 4 } & & $\mathrm{n}$ & 74 \\
\hline
\end{tabular}

3. ábra. A válaszadó szakiskolai pedagógusok véleménye arról, hogy az általuk tanitott tanulásban akadályozott fiatalok képes lesz-e megállni a belyét a szakmájában. Forrás: Szerző́k.

Ön szerint a tanulásban akadályozott fiatal képes megállni a helyét a szakmájában.

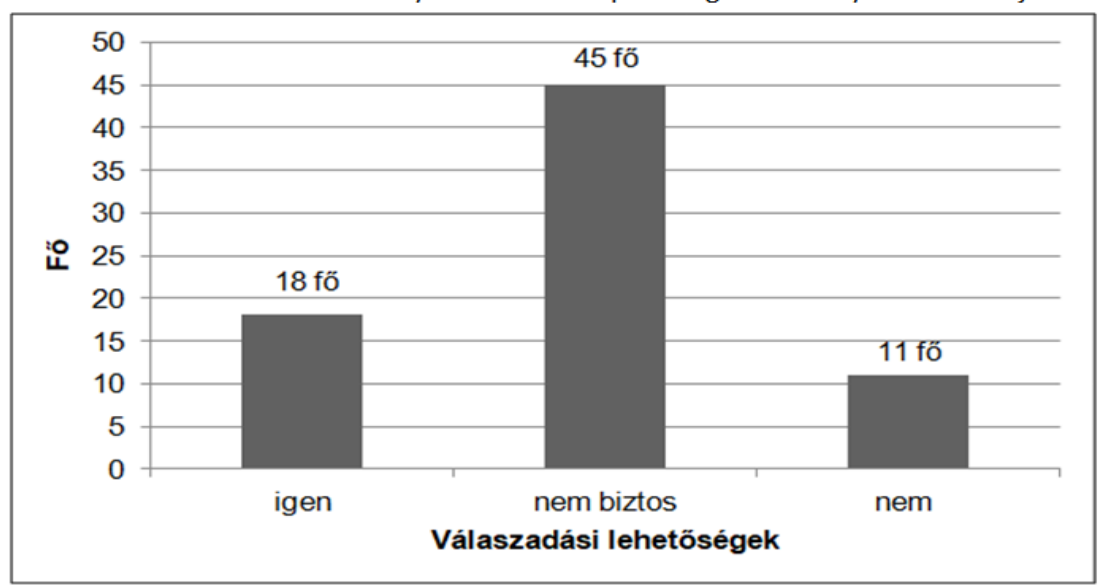


5. táblázat. A tanulásban akadályozott fiatalok életkilátásaira vonatkozó pedagógusi vélemények közötti a családalapitás és a családeltartása közötti együttjárás tekintetében. Forrás: szerzớk.

\begin{tabular}{|l|l|l|r|}
\hline \multicolumn{2}{|c|}{ Változók } & $\begin{array}{r}\text { El fogja tudni tartani a } \\
\text { családját, meg fog tudni } \\
\text { mindent adni nekik. }\end{array}$ \\
\hline $\begin{array}{l}\text { Spearman-féle } \\
\text { rangkorreláció }\end{array}$ & Alkalmas a családalapításra. & $\mathrm{r}_{\mathrm{s}}$ & 0,41 \\
\cline { 3 - 5 } & & $\mathrm{p}$ & 0,00 \\
\cline { 3 - 4 } & $\mathrm{n}$ & 74 \\
\hline
\end{tabular}

A negyedik hipotézisünk a családalapítás alkalmasságára vonatkozott és azt vizsgáltuk, hogy a pedagógusok mit gondolnak arról, hogy van-e összefüggés azzal, hogy el tudják majd tartani a jövőben a családot a szakiskolába járó tanulásban akadályozott fiatalok. Ebból szerettük volna kiszúrni azt, hogy a pedagógusok véleménye szerint a családalapítás alkalmassága mellett a fiatalok milyen mértékben gondolnak bele a jövőbe, a család eltartásával kapcsolatos teendôkbe, az alapvetô szükséglet kielégítésére (5.táblázat).

A két változó (családalapítás és családeltartás) között mérsékelt együttjárás $\left(\mathrm{r}_{\mathrm{s}}=0,41\right)$ van, a pedagógusok véleménye szerint a szakiskolába járó tanulásban akadályozott fiatalok alkalmasak a családalapításra, és úgy vélik, hogy azok, akik családot alapítanak valószínúleg elfogják tudni tartani a családjukat. De a mérsékelt korreláció arra figyelmeztet, hogy nincs konszenzus e tekintetben a szakiskolában dolgozó pedagógusok véleménye tekintetében (5.táblázat).

\section{Megvitatás}

A tanulásban akadályozott fiatalok jövőképének megismerésére irányuló vizsgálatunkban, egyrészt az életcélok, másrészt az életkilátások elemzésére került sor. Az életcélok tekintetében - elvárásainkkal ellentétben - a szakiskolába járó tanulásban akadályozott fiatalok nem a családalapítást jelölték meg elsődleges életcélként, ehelyett inkább a boldog életet, a sikereket és a munkát tartották fontosnak. Ez magyarázható az életkorral, hiszen középiskolás fiatalokról van szó, másrészt a munka iránti kedvező attitűd kialakulásaként is értelmezhetô.

A vizsgálatunk előtt, úgy véltük, hogy a fiatalok életcéljai között nem szerepel a továbbtanulás. A feltételezésünk abból táplálkozott, hogy eleve kevesebb szakmaválasztási lehetôség adott a tanulásban akadályozott tanulók számára (lásd: Szakmajegyzék), s így kevésbé találnak a későbbiekben az érdeklődésüknek és a képességeiknek megfelelő képzést. A feltevésünk igazolódott, nem mutatkozott szoros korreláció a két változó között (2. táblázat). Ugyanakkor pozitív tapasztalat, hogy a tanulásban akadályozott fiatalok céljai között is megjelenik a továbbtanulás, esetükben más szakma tanulása.

A jövőben a Lifelong Learning program szellemében, a tanulásban akadályozott szakiskolások továbbképzési lehetőségeinek átgondolására is szükség lehet, valamint az új rövid és hosszabb időtartamú továbbképzések kialakítására nagyobb hangsúlyt fektetni.

A harmadik hipotézis az életkilátásokra vonatkozott, melyben feltételeztük, hogy a szakiskolában tanító pedagógusok úgy vélik, hogy a fiatalok esetében a tanult szakma elsajátításának sikeressége 
összefüggésben van azzal, hogy képesek lesznek-e a késóbbiekben megállni a helyüket a munkaerőpiacon, a tanult szakmájukban. A két tényező között nincs szoros korreláció (4.táblázat), tehát hipotézisünk cáfolódott. Mindezt kedvezőtlen hatásként értelmezzük, mivel a vizsgálatunk is alátámasztotta azt a tényt, hogy a sajátos nevelési igényú tanulók elhelyezkedési esélyei lényegesen kedvezőtlenebbek az ép társaiknál (bôvebben: Mező K., 2021).

A negyedik hipotézis a családalapításra vonatkozott, miszerint, feltételeztük, hogy a szakiskolában tanító pedagógusok úgy vélik, hogy a szakiskolába járó tanulásban akadályozott fiatalok alkalmasak a családalapításra, valamint hogy el fogják tudni tartani családjukat és meg fognak tudni adni számukra mindent, amire szükségük lehet az életük során. Feltevésünk igazolódott, van összefüggés a két változó között (5. táblázat). Mindez részben azonos Lányiné (2017) azon véleményével, hogy a tanulásban akadályozott fiatalok alkalmasak a családalapításra, ugyanakkor ebben az esetben a családeltartásra vonatkozóan nem jelentek meg tapasztalatok.

A tanulásban akadályozott fiatalok életcéljai között lényegében ugyanazok fogalmazódnak meg, mint amit bárki elszeretne érni: hogy tudjanak spórolni, hogy boldog életet éljenek, hogy sikeresek legyenek és, hogy legyen munkájuk. Mindebből arra lehet következtetni, hogy pozitív jövőképpel állnak az élet felé. Ugyanakkor a velük foglalkozó pedagógusok már árnyaltabban fogalmaznak az életkilátások tekintetében. A pedagógusok úgy vélik, hogy azok a fiatalok, akiket érdekeli a jövője, azok képesek lesznek a társadalom aktív tagjává válni, sôt róluk azt gondolják, hogy a többségüknek lesz munkája. Ugyanakkor azt is vélik, hogy még ezek a fiatalok is hátrányban lesznek a munkaerôpiacon való elhelyezkedésben. Ez a vélemény sajnos kedvezőtlen a fiatalok jövőképe szempontjából. Az eredmények arra bíztatnak, hogy szükséges egy nagyobb mintaszámú kutatásra annak érdekében, hogy reálisabb kép alakuljon ki a témáról.

\section{Korlátozások}

A mintaszám korlátját érdemes megemlíteni. A kis minta a COVID19 járvány okozta bezárások miatt alakult ki, ebből következően a megfogalmazott tapasztalatokat célszerú a jelen kutatásra vonatkozó tartalomként értelmezni, és a jövőben egy nagyobb mintaszámú vizsgálat keretében ismételten átgondolni.

\section{Összefoglalás}

A vizsgálat alapján elmondató, hogy a tanulásban akadályozott fiataloknak hasonló céljaik vannak, mint ép társaiknak, azonban a fiatalok és az őket oktató pedagógusok véleménye között nincs teljes egyetértés. A tanulásban akadályozott fiatalok jövőképét azzal lehetne javítani, ha lehetőség nyílna az érdeklődésüknek és képességeiknek megfelelő szakmatanulásra; majd ezt követően olyan hivatás választására, amivel esélyük, lehetőségük van elhelyezkedni a munkaerőpiacon.

A munkaerőpiaci elhelyezkedés javítása fontos célkitűzés lehet a tanulásban akadályozott fiatalok esetében is, hiszen a munka teremti meg a lehetôségét az általuk vágyott sikeres, boldog életnek. Az élethosszig tartó tanulás programja (Lifelong Learning - LLL) - Memorandum az egész életen át tartó tanulásról (I1-EC, 2000), egyértelmúsíti az egész életen át tartó tanulás lehetőségének biztosítását és szükségességét mindenki számára. Mivel a tanulásban akadályozott fiatalok esetében kevésbé számolhatunk a jövőben az önképzés alapú tanulás megvalósulásával, ezért a formális továbbtanulási, továbbképzési lehetőségek megteremtésével kellene biztosítani a fiatalok munkában való folyamatos megújulásának az elérését, és ezáltal a sikeresség érzésének fenntartását, melyhez a szakiskola rendszere (a szakképzés rendszere, mint felnőttképzés) nagyban hozzájárulhatna. 


\section{Irodalom}

Bánfalvy Csaba (2005). A fogyatékos emberek és a munka világa. Szakképzési Szemle (2). 80-192.

Bernstein, Basil (1975). Nyelvi szocializáció és oktathatóság. In Pap Mária, Szépe György szerk.: Társadalom és nyelv. Szociolingvisztikai írások, Gondolat, Budapest. 393-434

Emmons, R. A. (1999). The psychology of ultimate concerns. Guilford, New York.

Goslin, David A. (1969). Handbook of socialization theory and research. Chicago, Rand McNally.

Hablicsek László, Kovács Katalin (2007). Az. életkilátások differenciálódása iskolázottság szerint 1986-2005.KSH, Budapest.

Központi Statisztikai Hivatal (2011.) - 2011. ÉVT NÉPSZAMLÁLÁS 17. A fogyatékossággal élōk helyzete és szociális ellátásuk. Budapest.

Központi Statisztikai Hivatal (2016). Mikrocenzus 2016. A fogyatékos és az egészségi ok miatt korlátozott népesség jellemzői. Budapest.

Lányiné Engelmayer Ágnes (2017). Intellektuális képességzavar és pszichés fejlödés. Medicina Könyvkiadó Zrt. Budapest.

Mártonfi György, Papp Gabriella \& Péceli Melinda (2011). Út a munkaeröpiacra - speciális szakiskolákból. OFI, Budapest.

Mező Ferenc, Mező Katalin (2020). Innovációs Stúdium. K+F Stúdió Kft, Debrecen.

Mező Katalin (2021). Tanulásban akadályozott fiatalok hátránykompenzációja a szakiskolában. Debreceni Egyetem, Debrecen.

Molnár Alexandra (2020). A tanulásban akadályozott fiatalok életcéljai és életkilátásai. OTDK pályamű.
Móré Mariann, Mező Katalin (2016). Fogyatékossággal élők a tanulástól a munkavállalásig. Különleges Bánásmód folyóirat, II. évf., 2016/1. szám, 17-26. doi 10.18458/KB.2016.1.17

Ryan, Richard M.; Sheldon, M. Kennon; Kasser, Tim; Deci Edward L.(1996). All Goals are not Created Equal. Psybology of Action.7-21.

Szakképzés 4.0. (2019). Szakképzés 4.0 - A szakképzés és felnőttképzés megújításának középtávú szakmapolitikai stratégiája, a szakképzési rendszer válasza a negyedik ipari forradalom kihívásaira. Innovációs és Technológiai Minisztérium, Budapest.

Szociális és Gyermekvédelmi Főigazgatóság (2017). Megváltozott munkaképességü személyek foglalkoztatásáról szóló munkaeró-piaci elörejelzése. Prognózis 2017. Budapest.

Zolnai Erika (2001). Értelmet az életüknek... In Falvai R. (szerk.), Értelmet az életüknek... [Fész̨ek szakmai füretek, 2]. Budapest: Kézenfogva Alapítvány. 11-13

I1: A Memorandum on Lifelong Learning. Comission Staff Working Paper. Comission of the European Communities. Brussels, 30.10.2000 SEC(2000) 1832. Letöltés: 2021.03.15. link: https://arhiv.acs.si/dokumenti/Memorandum_ on_Lifelong_Learning.pdf 